\title{
Development of Active Learning and Assessment Combination of Teacher Centre Learning and Student Centre Learning for Undergraduate Cell Biology
}

\author{
Netty Suharti ${ }^{1, *}$, Yohannes Alen ${ }^{1}$ \\ ${ }^{1}$ Faculty of Pharmacy,Andalas University, Padang, 25163 . Indonesia \\ *Corresponding author. Email .nettysuharti59@gmail.com
}

\begin{abstract}
The student-centered learning (SCL) is encompassed in learning which provides students to take an active role as the center in the learning process, to develop all its potential and explore the field of science, then reach its competence through an active, interactive, collaborative, and independent learning process. The process of learning is a cycle of being involved in a new experience (concrete Experimentation), assessing the larger context (Reflection), doing some research, discuss with others and applying the knowledge we already know to the situation (Abstract Conceptualization), doing something new or doing the same thing based on our learning (Active Experimentation). Cell Biology course is a compulsory subject to study about cells, which contributes to the competence of learning in Bachelor of Pharmacy program in the form of students' understanding of cells as a basic unit of life. Determining the level of understanding of students in this lecture is relies on the performance, result and also the process of their assignment in completing task by learning outcomes. The learning method that has been applied is the Teacher Centered Learning (TCL), where the learning achievement measures applied are the mid- term score, individual assignments and final exam. The students' final score are distributed as A $10 \%, \mathrm{~B} 50 \%, \mathrm{C} 30 \%$ and D is $10 \%$. The teaching method practiced so far with TCL has been inadequate to achieve educational goals based on learning outcomes. Therefore, the selection of assessment techniques must be adjusted to the learning outcomes and the level of competence desired by students at certain stages of their learning process. Through classroom action research (PTK) activities in this activity, research on the application of learning methods in the form of a combination of TCL and SCL was conducted. In this method, the lecturer gives lecture material for 4 meetings, then at the subsequent 3 meetings, a small group of students is given topic, discussing one of the topic of cells. The topic was initially discussed in a small group of 3 students, then presented in front of the class. The results of the observation showed that at the time of presentation the students were understand and able to explain the cells, including cell structure, function, cell membrane, cell physiology, cell environment, cell communication, cell environment, and apoptosis, correctly. This result is supported by the midterm examination, quiz, and presentation score which has increased as, A $23.89 \%$, A- $40.299 \%$, B +20.899 , B $8.4 \%$, and C $6.3 \%$, compared to the score within the previous period of TCL learning system only.
\end{abstract}

Keywords: Learning method, Teacher Centered Learning, Student Centered Learning, combination of TCL and SCL

\section{INTRODUCTION}

The student-centered learning (SCL) is encompassed in learning which provides students to take an active role as the center in the learning process, to develop all its potential and explore the field of science, then reach its competence through an active, interactive, collaborative, and independent learning process. [1]. The process of learning is a cycle of being involved in a new experience (concrete experimentation), assessing the 
larger context (reflection), doing some research, discuss with others and applying the knowledge to the situation (abstract conceptualization), doing something new or doing the same thing based on our learning (active experimentation). [2]. Student centered learning is defined as an approach to learning in which learners choose not only what to study but also how and why that topic might be interested [3]. In other words, the learning environment has learner responsibility and activity at its heart, in contrast to the emphasis on instructor control and the coverage of academic content found in much conventional teaching $[3,4]$. There has been increased emphasis in recent years on moving away from traditional teaching toward student-centered learning. This paradigm shift has encouraged moving power from the instructor to the learner, treating the learner as a co-creator in the teaching and learning process [5,6]. Instructors who deliver studentcentered learning method allow learner decide about how and what they learn and how that learning is assessed, and that they respect and accommodate individual differences in learners' backgrounds, interests, abilities, and experiences [7,8]. The role of the instructor in student- centered learning method in the classrooms is to encourage learners to do more discovery learning and to learn from each other; the instructor focuses on constructing authentic, real-life tasks that motivate learner participation and involvement $[9,10]$.

\section{BACKGROUND}

\subsection{Cell Biology subject}

Cell Biology subject is a compulsory subject that contains the subject matter of cells, the history of cell biology, types of cells prokaryotic, cells eukaryotic, parts of the cell, cell membrane, cell organelles . In this course also discussed the development of cells nd apoptosis. This course contributes to the competence or achievement of internal learning in Pharmacy undergraduate study program curriculum in the form of students understanding of cells as basic of life which is a vision of the Pharmacy undergraduate study program, Faculty of Pharmacy, Andalas University.

So far the teaching materials that have been developed are in the form of hand outs, power points, modules, and textbooks. The learning method that has been applied so far is Teacher centered learning, where lecturers give more material. Learning patterns that are centered on the lecturer or TCL as practiced at this time are not sufficient to achieve educational goals based on learning outcomes. Future learning is driven to be student- centered or SCL by focusing on learning outcomes $[11,12,13]$. The difference between TCL and SCL are: in TCL, students put all of their focus on the teacher. The teacher talk and students exclusively listen. During activities, students work alone and collaboration is discouraged $[14,15,16]$.

1. When using teacher- centered learning method, the classroom remains orderly. The student is quite, and the teacher retains full control of the classroom and its activities.

2. Because students learn on their own, they learn independence and make their own decision

3.Because the teacher directs all classroom activities, they don't have to worry that students will miss an important topic.

Consequences

1. Students have lower chance to collaborate with others when working alone.

2. Teacher centered learning method can be monotonous, and students may miss important facts if their mind wander.

3. in Teacher centered learning method, the opportunity for students to express themselves, and direct their learning is limited

When using student-centered learning method, students and lecturer share the focus.

Process

1. In student- centered learning method, Students learn about the importance of collaborative skills and communication through group working.

2. Students have more opportunities to ask questions, direct their learning, and complete assignment independently

3. When students can interact with others and participate actively, they are more interested in learning activities

\section{Consequences}

1. The classroom can be noisy because because the students are all talking.

2. the teacher will have difficulty managing all students activities at once, because students are working at different phase of the same project. 
3. Some students may miss important information because the teacher doesn't always deliver instruction to all students at once,

4. Work in group can be challenging, because some students prefer to work individualy.

\subsection{The change from TCL to SCL}

The change from TCL to SCL is a paradigm shift, namely a change in the mindset, namely: a) from knowledge that is seen as something that has been finished that is left transferred from the lecturer to the student into knowledge as a result of construction or transformation by students; b) learning is accepting knowledge into learning actively seeking and constructing knowledge; and c) lecturers convey knowledge or teach to become lecturers participating with students to form knowledge. In contrast at SCL, students work to provide a response to a central question. Since students must sort out for themselves what they need to do and know in order to develop this response, scl approached are more likely to promote student ownership over their process and learning than do teacher-direct approachees $[17,18]$. Lecturers design various methods so that students can choose the right way of learning, the lecturer acts as an instructor and facilitator and motivator.

At TCL, students work to meet the objectives set by teacher/lecturers. carry out lectures for 14 weeks, then conduct assessments during the Midterm Examination (UTS) and Final Semester Examination (UAS). The ability of new students can be known after the learning process ends, namely the completion of the Final Semester Examination (UAS) implementation. The problem is, the lecturer does not have the time to correct student weaknesses. The differences between TCL and SCL methods

Table 1. the differences between TCL and SCL methods

\begin{tabular}{|l|l|l|}
\hline No & TCL & SCL \\
\hline 1 & Focus is on teacher/instructor & Focus is on both student and teacher/instructor \\
\hline 2 & Lecturer/intructor talk, students listen & $\begin{array}{l}\text { Instructor models, students interact with instructor } \\
\text { and one other }\end{array}$ \\
\hline 3 & Student work alone & $\begin{array}{l}\text { Students work in pair, in group, or alone depending } \\
\text { on the purpose of the activity }\end{array}$ \\
\hline 4 & $\begin{array}{l}\text { Instructor monitors and corrects every } \\
\text { student utterance }\end{array}$ & $\begin{array}{l}\text { Students talk without constand instructor minitoring, } \\
\text { instructor provides feedback/correction when } \\
\text { questions arise }\end{array}$ \\
\hline 5 & Instructor answers students questions & $\begin{array}{l}\text { Students answer each other's question, using lecturer } \\
\text { as an information resource. }\end{array}$ \\
\hline 6 & Lecturer chooses topics & Students have some choice of topics \\
\hline 7 & Lecturer evaluates student learning & $\begin{array}{l}\text { Student evaluate their own learning, lecturer also } \\
\text { evaluate }\end{array}$ \\
\hline 8 & Classroom is quiet & Classroom is sometime noisy and busy \\
\hline
\end{tabular}

In our research on Cell Biology subject, the learning plan is focused on the combination of teacher centered learning (TCL) and student centered learning (SCL) and the process of being one with the assessment of learning outcomes by developing an assessment system in learning activities. Assessment is an activity of measuring the quality of knowledge, skills, and attitudes of students, or all three, which are 
the results of the learning process. Because of this, the selection of assessment techniques must be adjusted to the learning outcomes and the level of competence desired by students at certain stages of their learning process. Along with the application of a curriculum that integrates the IQF and SNPT, the learning and research methods must meet SNP standards. Thus, the learning system innovation must support four learning achievement elements in the IQF, namely 1) attitudes and values, 2) work ability, 3) scientific mastery, and 4) authority and responsibility. Through classroom action research (PTK) activities in this activity learning methods will be applied in the form of a combination of TCL and SCL.

The assessment carried out in measuring student learning outcomes applied so far is the value of UTS, the value of independent tasks in the form of presentations and UAS scores. The distribution of final grades in the previous semester is normally distributed with $\mathrm{A}, \mathrm{B}^{+}, \mathrm{B}, \mathrm{C}, \mathrm{D}$ and $\mathrm{E}$ was $7.35 \%$, $13.23 \%, 14.7 \%, 22.65 \%, 17.64 \%, 7.35 \%, 4.41 \%$ respectively.

\section{METHODOLOGI OR OUTPUT OUTCOME STRATEGY}

In this Class Action activity the learning method that have applied is a combination of TCL and SCL, a mix of the two approaches can created a wellbalance educational atmosphere, and that all have a right to be heard. In TCL the lecturers gave lecture material for 4 meetings, then at the next 3 meetings students were given topics each discussing one type of the history of cell biology, structure and fuction of cell, types of cells prokaryotic, cells eukaryotic, parts of the cell, cell membrane, cell organelles, cell communication, cell environment, cell cycle, the development of cells and apoptosis.

The topic was initially discussed in a small group of 3 students, then all the students in group was referred to coordination and prepare the each topic to presentation, then presented in front of the class. The resulting output is in the form of: (i) new RPS; and (ii) PTK results articles from the development of learning methods, curriculum, learning technology, and student assessments.

a. The learning plan outlined in the previous RPS or RPB will be improved to become a more perfect RPS or new RPB so that it can be used as a guideline for students in the learning process.

b. The development of the proposed learning method clearly describes the selection of learning methods in a combination approach between TCL and SCL, planning and implementation.

c. The assessment of student lecturers conducting student assessments in the achievement of student learning outcomes includes the assessment of processes and results, with the selection of assessment techniques in accordance with the level of competence planned in the RPS or RPB.

d. The proposed curriculum describes the current curriculum and plans for future curriculum changes.

e. The planned learning technology describes the technology that is being and will be applied in the learning process so that it supports the learning achievement.

f. PTK parameters include: (a) learning outcomes; (b) the distribution of the final value; and (c) student responses to the development of learning methods and / or assessments applied.

The Weekly Learning Activity Plans were consist of the expected final ability, material study, orm of learning, allocation of time, indicator criteria and value. The student expected understand and can explain the material study.

\section{RESULT AND DISCUSSION}

The result from this study in cell biology class, the learning plan is focused on the combination of teacher centered learning (TCL) and student centered learning (SCL) and the process of being one with the assessment of learning outcomes by developing an assessment system in learning activities with medium participant 69 student were showed in table 1. 
Table 2. the final grade cell biology with medium participant (69 student)

\begin{tabular}{|l|l|l|}
\hline Grade & Sum of participant & Persence (\%) \\
\hline A & 18 & 26.08 \\
\hline $\mathrm{A}^{-}$ & 40 & 57.97 \\
\hline $\mathrm{B}^{+}$ & 4 & 5.79 \\
\hline B & 3 & 4.34 \\
\hline $\mathrm{B}^{-}$ & - & - \\
\hline $\mathrm{C}^{+}$ & 4 & 5.79 \\
\hline D & - & - \\
\hline Sum & 69 & 100 \\
\hline
\end{tabular}

Based on the result of study, it can be seen that students get grades $\mathrm{A}, \mathrm{A}^{-}, \mathrm{B}^{+}$and $\mathrm{B}$ are $26.08 \%$, $57.97 \%, 5.79 \%, 4.34 \%$ respectively. The lowest grade is C $8.82 \%$, and no students get grade D. Although in some studies the SCL approach is more recommended than TCL, in this case the combination of TCL and SCL provides better results for students' grades. We can recommended in this case the best teaching is not one or the other, but combination of both. Lecturer positively impact students on many levels, including curriculum design, intelectual challenge, personal growth, career guidance and other less tangible ways. On the other hand the student also know that lecturer as a people who listen to their aspirations and struggles. Students memories and experiences with lecturers are often just as important to their success as the skills they develop and knowledge they acquire. So the choiced of joining together tcl and scl is better than TLC or SCL one.

\section{CONCLUSION}

Based on research conducted on the development of Learning and Assessment in Medium Class Cell Biology for Undergraduate on 2019-2020 with a total of 68 students it can be concluded that the application of learning with a combined method of TCL and SCL can improve student scores, with changes in student values compared to the TCL method given previously.

\section{ACKNOWLEDGMENT}

This work suppor by Andalas University Educational Development and Quality Assurance Institutions (LP3M) funding on 2020.

\section{REFERENCES}

1. Brush T and Saye J. 2000. Implementation and Evaluation of a student centered learning unit: a case study. Educational Technology Research and Development 48(3), 79-100.

2. Kolb, David A. 1984. Experiential learning: experience as the source of learning and development. Prentice-Hall,Inc, New Jersey.

3. Al Rawi, Ismail (2013) Teaching Methodology and Its Effects on Quality Learning. Journal of Education and Practice, vol 4, No. 6. Retrieved on 29 June 2013, from http://www.iiste.org/Journals/index.php/JEP/articl e/view/4820

4. Pedersen S, Liu M. 2003. Education Technology Research and Development. Springer 51 (2), 57.

5. Barr, R., \& Tagg, J. 1995. From teaching to learning. A new paradigm for undergraduate education. Change, 13-25.

6. Cannon, R. 2000. Guide to support the implementation of the Learning and Teaching 
Plan Year 2000. Australia: The University of Adelaide.

7. McCombs, B. \& Whistler, J. 1997. The learner centered classroom and school: Strategies for increasing student motivation and achievement. San Francisco: Jossey-Bass Publishers.

8. Yusoff, N.M., Karim, A.M.A., Othman, R., Mohin, M., \& Rahman, S.A.A. 2013. Studentcentred learning (SCL) in the Malaysian Higher Education Institutions. AJTLHE: ASEAN Journal of Teaching and Learning in Higher Education, 5(2), 14-33. Retrieved from http://journalarticle.ukm.my/6493/1/2_AJTLHE_ 101-nurahimah.pdf

9. Zain, S.F.H.S., Rasidi, F.E.M., \& Abidin, I.I.Z. 2012. Student-Centred Learning In MathematicsConstructivism In The Classroom. Journal of International Education Research (JIER), 8(4), 319-328.

10. Richard A. s. Castle. 1991. Learning to teach. McGraw-Hill. http://scholar.google.co.id

11. Holzer SM. From construction to active learning. 2005 (cited November 2005). Available from: URL:http:// www.succeed.ufl.edu/innovators/innovator-2/ innovator002.html.

12. OíNeill G, McMahon T. 2005. Student-centered learning: what does it mean for students and lecturers? In OíNeill G., Moore S., McMullin B, editors. Emerging issues in the practice of university learning and teaching. Dublin: AISHE; 27-36

13. Farrell, A., \& McAvinia, C. 2012. The Place of the University Teacher in a Dynamic StudentCentred Curriculum: A Snapshot of Practice at NUI Maynooth. In J. Hughes, \& E. Tan (Eds.), The Dynamic Curriculum: Shared Experiences of On-going Curricular Change in Higher Education (pp. 92-105). Dublin: Dublin City University.

14. Froyd, J. \& Simpson, N. 2010. Student-Centered Learning Addressing Faculty Questions about Student-centered Learning. Retrieved from http://ccliconference.org/files/2010/03/Froyd_Stu -CentredLearning.pdf

15. Noonan, E., \& O’Neill, G. 2012. Student Engagement and Assessment. In J. Hughes, \& E. Tan (Eds.), The Dynamic Curriculum: Shared Experiences of On-going Curricular Change in
Higher Education (pp. 72-91). Dublin: Dublin City University.

16. Powell, M. 2013. 5 Ways to Make Your Classroom Student-Centered. Education Week. Retrieved from http://www.edweek.org/tm/articles/2013/12/24/ct q_powell_strengths.html

17. Wright, G.B. 2011. Student-Centered Learning in Higher Education. International Journal of Teraching and Learning in Higher Education, 23(3), 92-97. Retrieved from http://files.eric.ed.gov/fulltext/EJ938583.pdf

18. Yurgudúl, H. 2008. Minimum sample size for Cronbach's coefficient alpha: A Monte Carlo study. Hacettepe Üniversitesi Journal of Education, 35, 397-405. Retrieved from http://www.efdergi.hacettepe.edu.tr/200835HAL $\%$ C4\%B0L\%20YURDUG\%C3\%9CL.pdf 